\title{
AMINOPYRALID - A NEW HERBICIDE FOR THE CONTROL OF BROADLEAF WEEDS IN PASTURES, CROPPING AND WASTELAND
}

\author{
S.R. FOWLER and B.M. HUSBAND \\ Dow AgroSciences, Private Bag 2017, New Plymouth, New Zealand \\ Corresponding author: bmhusband@dow.com
}

\begin{abstract}
Aminopyralid is a new pyridine carboxylic acid herbicide currently being developed around the world for the control of noxious and invasive weed species in pastures, crop and non-cropland areas. It is a broadleaf herbicide that provides systemic, post emergent control of annual, biennial and perennial weed species, agronomically important weeds and certain semi-woody weeds. Pasture grass species have excellent tolerance of aminopyralid at recommended use rates. In New Zealand, aminopyralid has been found to control a range of biennial and perennial broadleaf weeds at rates of $60 \mathrm{~g}$ active ingredient/ha as a broadcast application and a low volume spot application of $1.8 \mathrm{~g}$ ai/10 litres. As a stand-alone treatment aminopyralid controls important pasture weeds, including Arctotheca calendula, Carduus nutans, Carduus tenuiflorus, Cirisium arvense, Cirsium vulgare, Rumex obtusifolius, Senecio jacobaea and Silybum marianum. It has been found to be active on a range of perennial brushweeds making it a potential mixing partner with other herbicides for the control of Ulex europaeus, Rubus fruticosus and Cytisus scoparius. Aminopyralid is also being evaluated in formulations with other herbicides, including 2,4-D, clopyralid, fluroxypyr and triclopyr. Studies evaluating aminopyralid are continuing in pasture, forage brassicas and cereals. First registrations for aminopyralid are expected in 2005.
\end{abstract}

\section{EVALUATION OF WHOLE PLANT CHLOROPHYLL FLUORESCENCE TECHNOLOGY FOR RAPID ADJUVANT SYSTEMS PHYTOTOXICITY DETERMINATIONS}

\author{
J.A. ZABKIEWICZ \\ Plant Protection Chemistry, PO Box 6282, Rotorua, New Zealand \\ Corresponding author:jaz@ppcnz.co.nz
}

Photosynthesis is the metabolic process that distinguishes plants from other organisms. Many 'stress' factors can affect this process, and in so doing, affect the energy transfer cycle. One of the consequences is a change in fluorescence emission kinetics, which can be quantified. Although chlorophyll fluorescence measuring instruments have been available for many years, measurement of whole plant systems is very recent. The advantage is that the same individual regions or whole leaves on a plant can be monitored continuously, non-invasively and without the need for dark adaptation. This technology can also provide a clear (false colour) image of localised versus long distance effects on a plant, and can be used not only on foliage, but on fruit, seeds, and on any other chlorophyll containing organism. The current studies focussed on quantifying the effect of different adjuvants as a measure of their phytoblandness or contact phytotoxicity. It was also used to identify any effects on untreated parts, over a few minutes and at longer periods. These results were compared with known adjuvant behaviour characteristics. 